\title{
䫟顔面骨折術後の骨接合材の除去についての検討
}

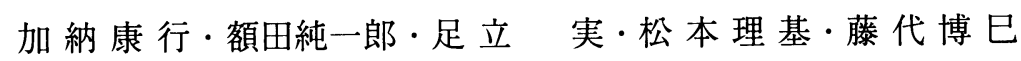 \\ 太田嘉幸·大前政利·内田 浩·作田正義
}

\section{A study on the removal of osteosynthetic materials following surgical treatment for maxillofacial fractures}

\author{
Yasuyuki Kano $\cdot$ Junichiro NuKata $\cdot$ Minoru Adachi \\ Riki Matumoto $\cdot$ Hiromi Fujishiro $\cdot$ Yoshiyuki Oнta \\ Masatoshi OHmae $\cdot$ Hiroshi Uchida $\cdot$ Masayoshi SaKuda
}

\begin{abstract}
Ninety-seven patients who had undergone internal fixation for maxillofacial fractures were examined with respect to the removal of osteosynthetic materials. All patients were scheduled to undergo removal of implant materials, but 16 patients refused. Among these patients, $64 \%$ refused because they did not wont to undergo a second operation, $18 \%$ because they feared facial nerve palsy, $18 \%$ because they feared an operation scar.

Osteosynthetic materials were removed in $67 \%$ of patients more than 40 years of ago and $87 \%$ of patients less than 40 years. Midface osteosynthetic materials were removed in $92 \%$ of male patients and $71 \%$ of female patients. Mandibular osteosynthetic materials were removed in $97 \%$ of patients treated with an intraoral approach and $63 \%$ of patients treated with an extraoral approach.

To facilitate the removal of midface osteosynthetic materials, operation should be done with an unmarked skin incision. To increase the removal rate of mandibular osteosynthetic materials, operation should be done with an intraoral approach, if possible.
\end{abstract}

Key words: removal of implant material (骨接合材除去), maxillofacial fracture（頢顔面骨折）, clinical investigation（臨床調査）

\section{緒袞}

近年, 顎顔面骨折に対して,ミニプレートを用いた 観血的整復固定術が多用されている ${ }^{1)}$. しかしながら このミニプレートなどの骨接合材の骨折治癒後の除去に ついて検討した報告はほとんど見当たらない，また，当 科では原則として骨接合材を除去する方針としているが, 患者が除去手術を希望せず留置する症例もある．そこで 今回，骨接合材除去の面から骨折処置方針の改善を計る ため, われわれは顎顔面骨折術後症例について骨接合材 除去の有無, さらには除去に至らなかった理由について

大阪大学歯学部口腔外科学第二講座

（主任：作田正義教授）

Second Department of Oral and Maxillofacial Surgery, Faculty of Dentistry, Osaka University (Chief: Prof. Masayoshi Sakuda)

受付日: 平成 7 年 10 月 23 日
調査および検討を加え，若干の知見を得たので報告する．

\section{対象症例と研究方法}

1988 年 7 月から 1993 年 6 月までの 5 年間に, 当科 にて観血的治療を行った顎顔面骨折 146 症例のうち, 骨接合術を行い 6 か月以上の経過観察を行い得た男性 73 例女性 24 例の計 97 症例 206 骨折線を対象症例とし た. 対象症例の年齢は, 男性は 3 歳から 56 歳で平均 25 歳, 女性は 4 歳から 65 歳で平均 30 歳であった.

これらの症例について骨折部位, 手術法, 骨接合材 除去の有無, 骨接合材除去を希望しない理由について の臨床統計的観察を行った.

\section{結果}

1. 骨折部位別および使用骨接合材別症例数 対象症例の骨折部位別症例数は, 下顎骨骨折 62 例, 
表 1 性別·骨折部位別症例数

\begin{tabular}{l|c|c|c}
\hline & 男性 & 女性 & 計 \\
\hline 下顎骨骨折 & 47 & 15 & 62 \\
\hline 顔面中 $1 / 3$ 骨折 & 24 & 7 & 31 \\
\hline 下顎骨骨折+顔面中 $1 / 3$ 骨折 & 2 & 2 & 4 \\
\hline \multicolumn{1}{c|}{ 計 } & 73 & 24 & 97 \\
\hline
\end{tabular}

表 2 顔面中 $1 / 3$ 骨折症例の性別 - 手術法別骨接合材 除去率

\begin{tabular}{c|c|c|c}
\hline & 男性 & 女性 & 計 \\
\hline 口外法 & $91 \%(20 / 22)$ & $67 \%(4 / 6)$ & $86 \%(24 / 28)$ \\
\hline 口内法 & $100 \%(2 / 2)$ & $100 \%(1 / 1)$ & $100 \%(3 / 3)$ \\
\hline 計 & $92 \%(22 / 24)$ & $71 \%(5 / 7)$ & $87 \%(27 / 31)$ \\
\hline
\end{tabular}

顔面中 $1 / 3$ 骨折 31 例，下顎骨と顔面中 $1 / 3$ の合併 骨折 4 例であった。使用した骨接合材別症例数は, Luhr ミニプレート 33 例 (34\%), Leibinger ミニプレー ト 23 例 $(24 \%)$, Luhr ミニおよびマイクロプレート 16 例 (16\%), Champy ミニプレート 5 例 $(5 \%)$, ワ イヤー 4 例 ( $4 \%$ ), その他 16 例（16\%）であった.

97 症例すべてにわれわれは骨接合材除去を勧め, こ のうち 81 例に骨接合材除去が行われた. Luhr ミニプ レートの除去率 82\%, Leibinger ミニプレートの除去 率 $87 \%$ など骨接合材の材質別除去率に大きな違いは 認められず, 術後感染などの合併症により骨接合材の 除去が必要となった症例はなかった。また，除去され た骨接合材の生体埋没平均期間は 409 日であった.

\section{2 . 性, 年齢別骨接合材除去率}

男性では 40 歳以上 $60 \%, 40$ 歳未満 $89 \%$,女性では 40 歳以上 $75 \%, 40$ 歳未満 $81 \%$ の除去率であった。男 女合計では 40 歳以上 18 例中 12 例 $(67 \%), 40$ 歳未満 79 例中 69 例 $(87 \%)$ であり，40 歳以上で除去率が低 下する傾向にあった。

\section{3. 骨折部位別の骨接合材除去率}

1 ) 顔面中 $1 / 3$ 骨折は観血的整復固定術に際して, ほとんどの症例に顔面皮膚切開が用いられた。この切 開は，眉毛外側およひ瞼縁あるいは下眼瞼に行われた。 これらの顔面皮膚切開症例の除去率は男性 91\%女性 67 \%であり，男性に比べ女性に除去率が低い傾向にあった。

2 ) 下顎骨骨折は観血的整復固定術に際して, 下顎 体部骨折は口内法が多く用いられ，関節突起部骨折は 顎角下部に切開を加え, 場合によっては耳前切開を併 用する口外法が用いられた。 また顎角部骨折では口外 法, 口内法両方法が使用され, 近年, 口内法を選択す る傾向にある. 関節突起部を除く下顎骨の他部位骨折 では除去率が $94 \%$ と高く，特に口内法症例では $97 \%$ と高い除去率であったが, 関節突起骨折では, 除去率

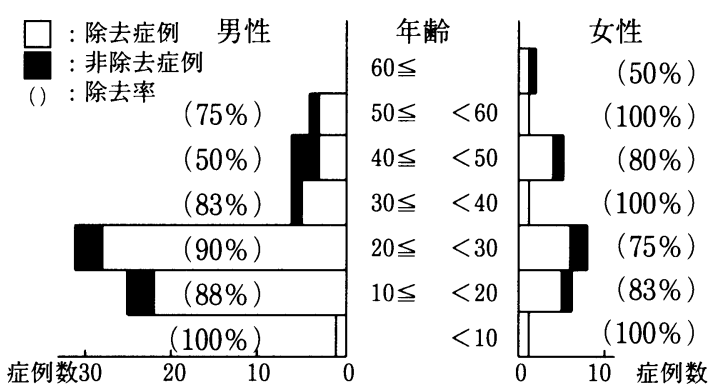

図 1 性別・年齢別骨接合材除去症例数

が36\%と低い值を示した。 また口外法による下顎骨骨 折症例の除去率は, 男性 17 例中 11 例 $(65 \%)$ 女性 7 例中 4 例 $(57 \%)$ であり，この性別除去率には顔面中 1 / 3 骨折のそれに比べ, 男女間の大差を示さなかった。

\section{4. 骨接合材の除去を希望しない理由}

骨接合材の非除去症例 16 例のうち調査可能な 11 例 について調べた結果，7例 $(64 \%)$ は骨接合術を行う 前から骨接合材の除去を望まず，残る4例（36\%）は 観血的処置により顔に傷がつくことに対する不安ある いは顔面神経麻瘏出現を危惧して望まなかった。顔に 傷がつくことを危惧した 2 症例は顔面中 $1 / 3$ 骨折で あり，顔面皮唐切開を要する症例であった，顔面神経 麻痺を危惧した 2 症例は関節突起骨折であった．関節 突起骨折 11 例では，受傷時の顔面神経麻痺を認めた 1 例を除いて，3例 $(30 \%)$ に観血的整復固定術後に軽 微な顔面神経麻痺が出現した。この 3 例中骨接合材除 去手術を行ったのは 1 例（33\%）であった．観血的整 復固定術後に顔面神経麻瘦が出現しなかった 7 例中骨 接合材除去手術を行ったものは 3 例 $(43 \%)$ であり， 顔面神経麻瘏が出現しなかった症例の方が若干骨接合 材除去率が高かった。 なお，これら顔面神経麻瘏はす べて顔面神経の下顎縁枝損傷によると考えられる軽微 な下唇運動麻痺で, 経過観察期間中にすべて消失した.

\section{考察 \\ 1. 骨接合材永久埋没の問題点について}

骨接合に際しては，そのほとんどの場合で金属製の 骨接合材が使用されている．Luhr プレートはバイ夕

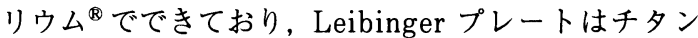
が主成分である。また Champy ステンレスプレート の組成は鉄・クロムなど 2 )である. Luhr プレートや Leibinger プレートは永久埋没可能とされているが, こうしたプレートを含め金属製骨接合材を留置してい ると, 将来骨接合材に感染を生じる可能性や，さらに 骨接合材の金属成分の溶出により金属アレルギーの発 生, 細胞障害の可能性が報告されている ${ }^{3,4)}$. この他 にも金属製骨接合材では CT, MRI の画像に障害陰影 を生じることや，ステンレスでは腫場発生の可能性が 
表 3 下顎骨骨折症例の性別・手術法別骨接合材除去率

\begin{tabular}{c|c|c|c}
\hline & 男性 & 女性 & 計 \\
\hline 関節突起骨折 (口外法) & $20 \%(1 / 5)$ & $50 \%(3 / 6)$ & $36 \%(4 / 11)$ \\
\hline 関節突起部を除〈他部位骨折 (口外法) & $83 \%(10 / 12)$ & $100 \%(1 / 1)$ & $85 \%(11 / 13)$ \\
\hline 関節突起部を除〈他部位骨折 (口内法) & $97 \%(29 / 30)$ & $100 \%(8 / 8)$ & $97 \%(37 / 38)$ \\
\hline 計 & $85 \%(40 / 47)$ & $80 \%(12 / 15)$ & $84 \%(52 / 62)$ \\
\hline
\end{tabular}

（）内は除去症例数 /対象症例数を示す

ある 5,6$)$ などの報告もある。また生体材料用金属と して親和性・耐蝕性に最も優れているとされているチ タンでもイオンの溶出が報告されており $3,4,7)$ ，骨接 合材の永久埋没では, さまざまな問題点があると考え られる．以上のことからわれわれは，原則として永久 埋没可能と言われている骨接合材を使用はしているが, 初回の骨折手術前に患者に骨接合材除去を勧めている.

\section{2. 顔面中 $1 / 3$ 骨折症例の骨接合材除去について}

顔面中 $1 / 3$ 骨折ではそのほとんどの症例で, 顔面 皮膚に切開を加える口外法によるアプローチで手術が 行われているため, 同部骨折例の $6 \%$ が顔に傷がつく ことを危惧して骨接合材除去を希望せず，中でも顔に 傷がつくことを特に危惧すると考えられる女性に骨接 合材除去率が低かった. 今後これらの結果を考虑に入 れ, 瘷痕の目立ちにくい切開法を選択し，傷跡を目立 たさなくすることが重要である.また骨接合材除去が 拒否される場合を考えて，より為害作用が少ないと考 えられる永久埋没可能と言われている骨接合材を使用

しておく事が大切であると考える。

\section{3. 下顎骨骨折症例の骨接合材除去について}

関節突起部を除く下顎骨の他部位骨折では，94\%の おおむね満足のいく除去率であった。しかし，主に口 外法によるアプローチにて軽微ではあるが顔面神経麻 瘏が生じやすい関節突起骨折では, その $33 \%$ が顔面神 経麻瘏出現を危惧して骨接合材除去を希望せず，除去 率が低かった。 また，関節突起骨折で観血的整復固定術 後に顔面神経麻痺を生じた症例は, 生じなかった症例よ りも骨接合材除去を希望しない傾㐰にあり, 除去率が低 かった. 以上のことから，関節突起骨折術後の骨接合材 除去率の向上には, 顔面神経麻㾇出現の可能性をできる だけ軽減させることが重要である。したがって, 手術手 技の向上や下顎角下部の剥離だけで骨接合材除去ができ, 顔面神経損傷の可能性が低い骨接合術 8 ) の実践などに ついて今後検討していく必要があると考えている.

\section{4. 再度の観血的処置を希望しない症例の骨接合材}

\section{除去について}

患者が骨接合材の除去を希望しない最大の理由は再 度の観血的処置を希望しないことであり,この問題解 決には，除去を必要としない，体内に異物として残存 しない骨接合材の開発が望まれる。実際このような骨 接合材使用の臨床報告 9 ）も散見されるが，いまだ日常
臨床の使用段階に至っていない。したがって現状では Leibinger プレート等の, 為害作用が少ないと考えられ る永久埋没可能と言われている骨接合材を，除去を予定 せずに使用することが,こうした症例への対応として最 善となると考える. 生体内で安全に吸収され，操作性の 良い強固な骨接合材の今後の開発に期待したい.

\section{結語}

1988 年 7 月からの 5 年間の, 顎顔面骨折術後症例 97 例を対象として骨接合材除去に関する検討を行った.

1. 口外法を用いた顔面中 $1 / 3$ 骨折では女性で, 下顎骨では関節突起骨折で除去率が低かった。

2. 40 歳以上の症例で除去率が低かった.

3. 患者が骨接合材除去を望まなかった理由は, 骨折手 術前から除去手術による再度の観血的処置を望まなかった ものが64\%であった. 残りは除去時の顔の傷跡を危惧した もの，および顔面神経麻痺を危惧したもの各18\%であった。

本論文の要旨は第 6 回日本口腔科学会近畿地方会 （1994 年 12 月, 大阪）において発表した.

\section{引用文献}

1) Tucker, M.R., Terry, B.C. et al.: Rigid Fixation for maxillofacial surgery. Lippincott Co, Philadelphia, 1991, P 3 -29.

2) Tucker, M.R., Terry, B.C. et al.: Rigid fixation for maxillofacial surgery. Lippincott Co, Philadelphia, 1991, P31-53.

3) Rosenberg, A., Grätz, K.W., et al.: Should titanium miniplates be removed after bone healing is complete? Int J Oral Maxillofac Surg 22: 185-188 1993.

4) Moberg, L., Nordenram, A., et al.: Metal release from plates used in jaw fracture treatment. Int J Oral Maxillofac Surg 18: 311-314 1989.

5) Black, J.: Orthopaedic biomaterials in research and practice. Churchill Livingstone, New York, 1988, p292.

6) Mcdougall, A.: Malignant tumour at site of bone plating. $J$ Bone and Joint Surg 38B: 709-713 1956.

7）関豊, 別所和久, 他: チタン製ミニプレー 卜に関する臨床病理学的検討．日口外誌 40 : 892-896 1994.

8) Eckelt, U., Gerber, S.: Zugschraubenosteosynthese bei Unterkiefergelenkfortsatzfrakturen mit einem neuartigen Osteosynthesebesteck. Zahn Mund Kieferheilk 69: 485-490 1981.

9）別所和久, 飯塚忠彦, 他：口腔外科領域におけ る生体内吸収性ポリー L 一乳酸骨接合ミニプ レートの開発と臨床応用。日口外誌 40: 105410591994. 